\title{
THE ORIGINS OF NIGERIAN FEDERALISM: The Rikerian Theory and Beyond
}

\author{
by Dele Babalola
}

School of Politics and International Relations, University of Kent, Canterbury,United Kingdom

Email: B.Babalola@kent.ac.uk

Abstract: Scholars of federalism have offered different reasons why federations are formed. One of the most notable works in this area is that of William H. Riker, who made no pretence about his attempt to build a general theory of federalism, particularly its origin, operation and significance. Central to the Rikerian theory is that federations are formed through a political bargain between two sets of rational politicians, and the motive for the federal bargain is principally military. This theory is predicated on the assumption that two conditions - the expansion condition, and the military condition must be present for a federation to be formed. In reference to the Nigerian Federation established in 1954, Riker asserted that the expansionist ambition of Ghana and its then leader Kwame Nkrumah, was the main external threat that informed the formation of the Federation. The main aim in this paper is to argue that the Rikerian theory of federal formation is inadequate to explain the origin of the Nigerian Federation, especially in the light of the centripetal and centrifugal forces that combined to result in the Federation.

Keywords: Nigeria, federalism, Rikerian Theory

Babalola, D. 2013, "The Origins of Nigerian Federalism: The Rikerian Theory and Beyond" Federal Governance, vol. 8 no. 3, pp. 43-54. 


\section{About Federal Governance}

Federal Governance is an online graduate journal on theory and politics of federalism and multilevel governance. Its mandate is to engage the global federalism community and reach out to outstanding graduate students interested in federalism and multi-level governance. By providing a platform for graduate students to have early success in their careers, Federal Governance seeks to promote and sustain interest in federalism and multi-level governance research among graduate students. Allied with the Forum of Federations and founding partner, Institute of Intergovernmental Relations at Queen's University; Federal Governance aims to contribute to a global dialogue on federalism.

Co Chairs, Advisory Committee:

Publisher:

Managing Editor:

Associate Editors:
Rupak Chattopadhyay and Christian Leuprecht

Forum of Federations

(Rupak Chattopadhyay and Philip Gonzalez)

Dominic Heinz

Maria Bertel, Carey Doberstein, Sean Müller, Eyene

Okpanachi and Samir Sharma

\section{Terms of Use}

Your use of this Federal Governance article indicates your acceptance of Federal Governance's Terms and Conditions of Use, available at www.federalgovernance.ca/terms. Federal Governance's Terms and Conditions of Use provides that you may use Federal Governance content only for personal, academic and non-commercial use. Each copy of any part of this Federal Governance article must contain the same copyright notice that appears on the screen or printed page of such transmission. 


\section{Introduction}

Scholars of federalism have, in varying degrees, emphasised the causal relationship between the origin and success or failure of federations. For instance, Hicks (1978: 5) has particularly suggested that the historic origin of federations affects "their Constitutions and the working thereof". Stepan (2001: 320) also reminds us that a distinction must be made between federations whose main purpose is to "come together", and those whose purpose is to "hold together". This explains why scholars often lay emphasis on the centripetal as well as the centrifugal forces that bring about a federal system of government. However, different explanations have been offered in this regard. In this paper, attempt is made to subsume these explanations under two theories: the socio-economic theory, and the political theory, with the former arguing that federations come into being as a result of the presence of certain social, economic, historical and geographical factors, whilst the latter, anchored by Riker, contends that federations result from the presence of some political forces. The political theory, otherwise referred to in this paper as the Rikerian theory, rejects the socio-economic explanation of federal formation.

Nigeria's federal experience began in 1954 under the tutelage of the British colonial authority and the fundamental aim of the Federation was to hold together the diverse groups that have been lumped together in the British-inspired contraption called Nigeria. The formation of the Nigerian Federation has elicited divergent views from scholars, but our main focus in this paper is to reject the Rikerian thesis, which rejects the presence of socio-economic conditions in the calculation to arrive at a federal political framework for the country. Therefore, our central argument is that the federal solution in Nigeria was necessitated by the desire to achieve 'unity in diversity' and this was made possible by the presence of certain socio-economic forces. Put differently, the paper brings to the fore the gaps in Riker's theory of origin of federations in general and that of Nigeria in particular. In this paper therefore, an attempt is made to shed more light on those circumstances that culminated in the Nigerian Federation, with a view to proving that the socio-economic theory of federal formation best explains the birth of the Federation.

The remaining part of the paper is divided into three main sections. The first examines Riker's political theory of federal formations in general, while the second, which focuses on the origin of the Nigerian Federation hinges upon those social, economic and political forces that paved the way for a federal system of government in Nigeria, and the third, which concludes the paper, highlights the flaws in the Rikerian theory of federal origin.

\section{Riker's Political Theory of Federal Formations}

As already mentioned, the most notable work on the political theory of origin of federations is that of Riker, who made no pretence about his attempt to build a theory particularly on the origin of federations, and the operation and significance of federalism. Riker's intention was to develop a political science that would provide "testable and tested generalisations", and he rationalised his decision to do this by lamenting that, 
As a political scientist, I have always regretted that much of what passes as scientific investigation in our field is no more than elaboration of unique detail, e.g., the case study of a particular event, the history of a particular institution, the evaluation of a particular policy, the description of a particular culture (Riker, 1964: xi).

Given this assertion, it becomes pertinent to begin with Riker's notion of federalism, as this may offer an insight into his theory. Riker defined federalism as "a bargain between prospective national leaders and officials of constituent governments for the purpose of aggregating territory, the better to lay taxes and raise armies" (ibid.: 11). Implicit in this definition is that the bargain is like a contract involving some offer and acceptance. It also implies that the 'rational' politicians making the offer must be convinced of the benefits derivable from the proposed union, while their counterparts accepting the offer would also have to be convinced that the advantages of belonging to the union outweigh the disadvantages. According to Riker,

The politicians who offer the bargain desire to expand their territorial control, usually either to meet an external military or diplomatic threat or to prepare for military or diplomatic aggression and aggrandisement. The politicians who accept the bargain, giving up some independence for the sake of union, are willing to do so because of some external military-diplomatic threat or opportunity. Either they desire protection from an external threat or they desire to participate in the potential aggression of the federation (ibid.: 13).

Riker's theory is therefore predicated on the assumption that federalism is an outcome of political bargaining among rational politicians, built upon a two-fold hypothesis: the expansion condition, and the military condition, which according to Riker, are necessary for the formation of a federation.

Riker began the formulation of his theory by bluntly dismissing earlier ideas on the formation of federations as "ideological" and "reductionist" fallacies, and particularly branded Deutsch's explanation of social and economic conditions as a "reductionist fallacy" (ibid.: 15). The main weakness of Deutsch's nine "essential conditions", he argued, is that it precludes the political aspect of federal formation - a political bargain between two sets of politicians. The following more aptly presents the argument against the Deutsch conditions: "in bypassing the political, in bypassing the act of bargaining itself, it leaves out the crucial condition of the predisposition to make the bargain" (ibid:: 16). Riker contended further that the list only provides a set of frequently observed conditions that propel politicians towards a predisposition to unite in some way or another. For Riker, therefore, earlier ideas on the formation of federations are ideological rather than scientific.

In an attempt to justify the validity of his data and also to demonstrate that his theory was scientific, Riker claimed to have examined "all the instances of the creation of a federalism since 1786, given most detailed attention to the invention of centralised federalism in the United States", and then concluded that "the military and expansion conditions are necessary to the occurrence of federalism" (ibid.: 13). This implies that these two conditions were particularly present in virtually all federations, including Nigeria. It is therefore important to verify briefly Riker's claim in some of the other federations he examined before focusing on Nigeria. 
Let us begin with Australia, where Riker conceded that economic factors cannot be completely ignored in the formation of the federation, and also that there was no immediate threat when the federation was formed. However, he pointed out that the presence of some "military-diplomatic concerns" informed the decision taken by the founding fathers of the country (ibid.: 27). The two main claims made by Riker regarding Australia can be summarised thus: that the formation of the Australian Federation was precipitated by the fear of Japanese imperialism in East Asia, and that because these threats were relatively weak, it was necessary only to create a relatively peripheralised federation that reflected the strength of provincial as opposed to national loyalties. In the case of India, Riker posited that the formation of the federation was occasioned by external threats from Pakistan, which was "more warlike, better armed, and more resentful", and internal threats from the princely states, which were "a collection of partially self-governing colonies in 1947" (ibid.: 29). Riker, however, recognised the influence of the constitutional engineering that culminated in the formation of the Indian Federation, particularly the influence of The Government of India Act of 1935, yet preferred to argue that the two forms of threat mentioned earlier combined to give birth to the Federation. For Malaysia, Riker asserted authoritatively that the formation of the Malaysian Federation fulfils his hypothesis. Specifically, he claimed that the military condition was present and was evidenced in "the existence of communist guerrillas, supported from China", whilst the expansion condition was also present due to the need to reconcile the previously federated states (ibid.: 31 ). He declared with certainty that, "the clearly discernible motive for this federalism was, therefore, a fear of Indonesian imperialism and a reluctance, on the part of Singapore, Borneo, and others to accept Malayan domination" (ibid.). Finally, in the case of Nigeria, Riker's position was that the main external threat that led to the formation of the Federation was the expansionist ambition of Ghana (we shall shed more light on this in the next section).

In a stunning criticism of Riker's theory of origin, Dikshit $(1971 ; 1975)$ asserted that Riker was neither the first nor the only scholar to point out the importance of a military condition or external threat, or the expansion condition, as this had been articulated by scholars before Riker, including William Maddox, H. R. G. Greaves and Kenneth Wheare. For example, Maddox (1941: 1122) had observed that some of the motivations behind the formation of federations are: fear, a calculated expectation of advantage, and a response to some unifying ideal or myth; but fear which may develop from direct attempts at intimidation, or from a sustained and profound feeling of insecurity, is the most important of these political or psychological forces. Dikshit (1975: 223) particularly dismissed Riker's theory as untenable on the ground that his own study of the federations of West Germany and Austria had demonstrated that Riker's so-called necessary conditions were absent.

Also critical of Riker's account of federal formation is Davis (1978: 133), who commenced his criticism of Riker's political conditions by arguing that all unions are formed, in the first place with the primary desire to promote the well-being of their members, implying that security is the underlying motive "in the calculation of all communities which seek greater strength through association". Another critic of Riker's theory is King (1982), observing that it is obvious that, to every state, there is always some risk of external war and domestic dissension, and that the source of risk is threefold: threat to a particular state from within the state; threat to one state from another state; and threat to allied states from another state (King, 1982: 35-6). In other words, threat from within the state may provoke that state to form a union, just like threat to one 
state from another may provoke a federation between them, and according to King, this appears to have been the case with the federations of the United States, Switzerland and Nigeria. Therefore, King observes that if the birth of a federation is predicated upon fear of other powers, then any type of fear must provide grounds for federal union; so, Riker's 'threat' criterion is unfounded.

Similarly, Stepan (2005) also criticised Riker's views on federal origin for focusing exclusively on the American model of federation, which represents the oldest and the most successful federation in the world. Perhaps in an attempt to simplify the debate on the origin of federations, Stepan chose to examine the modes of federal creation rather than the factors that give birth to federations, and therefore came up with the following three main typologies of federal formations: coming together; holding together; and putting together. In this categorisation, the American, Swiss and Australian Federations are referred to as "coming together" federations in that previously sovereign units had pooled their sovereignties while retaining their individual identities, and a "holding together" federation is when an existing unitary state, usually characterised by "historical and political logic", decides to become a federation, and finally, a "putting together" federation involves the use of coercion to put together previously independent states (Stepan, 2005: 257-8). Based on Stepan's typology, Nigeria and India exemplify holding together federations because the constituent units that merged to form the respective federations were not sovereign compared with the American states, whilst the former Soviet Union typifies a putting together federation.

It must be stated at this juncture that some scholars are sympathetic to the Rikerian theory. Notable among them is McKay (2004: 170), who observes that the main critique of the Rikerian theory revolves around Riker's insistence that the threats to external or internal security must always be present for a federation to be formed and must always be military/diplomatic in nature. McKay contends that Riker's theory cannot simply be flawed on the ground that all countries actually or potentially face threats, as claimed by other critics such as King. Pitching tent with Riker, McKay also argued that external threats may lead to annexation, treaty or war, and/or federation, especially when certain special conditions are met, and the level of threat will determine the particular arrangements arrived at. Nevertheless, McKay concedes that Riker's exclusion of the social and economic conditions is too restrictive because these factors were equally important to federal formation, but has praised Riker's theory for providing "us with the most effective heuristic tools at our disposal in this subject area" (ibid.: 182).

\section{The Socio-economic Theory and the Formation of the Nigerian Federation}

In regards to the origin of the Nigerian Federation, Riker specifically contended that the expansionist ambition of Ghana and its then leader Kwame Nkrumah was the main external threat that informed the formation of the federation. Without mincing words, Riker authoritatively argued that, "Nkrumah's emphasis on Pan-Africanism was at its height and no Nigerian leader could fail to be aware of the proximity of the Western (and depressed and minority) region of Nigeria to Ghana" (Riker, 1964: 31). The point being made here is that Nkrumah's idea of pan-Africanism was based on his personal ambition to bring the entire sub-continent of West Africa under his leadership. The internal threat, on the other hand, according to Riker, was "the unwillingness of Nigerian leaders to upset the bargain the British had made for them" (ibid.: 32). 
These assertions attracted a lot of criticisms from Nigerian scholars as well as those familiar with Nigeria's political history. One account of Nigeria's federal formation that could be easily juxtaposed with Riker's is that of Anthony Birch, whose views on Nigerian politics in general would seem more accurate given his sound knowledge of the country. Birch acted as consultant to the Western Region government from 1956 to 1958 (Birch, 1966: 23). Although, it could be argued that Birch served in Nigeria after the introduction of federalism yet his knowledge of the country cannot be overstated. Birch noted that nothing suggests that Nkrumah's Pan-Africanist ambition had any influence on Nigerian regional leaders' decision to opt for a federal political framework. Also, the Nigerian doyen of federalism, the late Professor Eme Awa, had contended that the main internal threat instrumental to the formation of the Nigerian federal union was the fear of insecurity felt by mainly some minority ethnic groups in the country (Awa, 1976: 19). Another critique of Riker's explanation in regards to the creation of the Nigerian Federation is Eleazu (1977: 18), who found Riker's explanation preposterous, arguing that the federal idea in Nigeria was conceived while Nkrumah was still in the United States studying, and besides, most Nigerian leaders shared, in varying degrees, the Pan-African ideology.

In a similar vein, Davis (1978: 126-6; 133) also dismissed Riker's work as belonging to the "quasi-scientific style of the behavioural movement", aspiring to transcend the "unique" historical and cultural setting of each federal experience to establish "tested and testable" generalisation, and also reporting his findings in a typical "lab- science mode of reporting", but he salutes Riker's courage for assigning a significant and constant responsibility to the military condition. In specific reference to Nigeria, Davis criticised Riker for translating history "with the reductionist zeal of a salvationist, an apocalyptic or materialist historian" (ibid.: 136). This implies that Riker either misunderstood or misinterpreted Nigerian political history, and this had resulted in an erroneous conclusion. As if echoing Awa, King (1982: 35) also argued that the potential threat within Nigeria was the fear of each of the three main Regions that the other two would combine against it. Similarly, Elaigwu (2006: 211) had argued that mutual fears and suspicions of domination among the different ethnic groups within the country reinforced the colonial authority's calculation to promote the idea of federalism in Nigeria. Consequently, it is clear from the various accounts that have been presented thus far that some threats partly acted to influence the federalising process, but these threats, contrary to Riker's assertion, were internal from other regions within the country, and not from outside.

Therefore, it becomes imperative at this juncture to turn our attention to the socioeconomic factors that usually result in the birth of federal unions. Very instructive here is Deutsch's explanation of social and economic conditions that give rise to federations. These conditions are as follows:

1) Mutual compatibility of main value; 2) a distinctive way of life; 3) expectations of stronger economic ties or gains; 4) marked increase in political and administrative capabilities of at least some participating units; 5) superior economic growth on the part of at least some participating units; 6) unbroken links of social communication, both geographically between territories and sociologically between different social strata; 7) a broadening of the political elite; 8) mobility of persons at least among the politically relevant strata; and 9) a multiplicity of ranges of communications and transactions (see Riker 1964: 15). 
According to Birch, of the nine conditions postulated by Deutsch, the following four were instrumental to the establishment of Nigeria's federal system: expectations of stronger economic ties or gains; a marked increase in political and administrative capabilities of at least some participating units; superior economic growth on the part of at least some participating units; and a multiplicity of ranges of communications and transactions.

Also important here is Wheare's position that some political, social and economic factors combined to contribute to the formation of federations, and these particularly informed the formation of the federation of the United States, Switzerland, Canada and Australia, and they include:

1) A sense of military insecurity and of the consequent need for common defence; 2) $A$ desire to be independent of foreign powers, and a realisation that only through union could independence be secured; 3) A hope of economic advantage from union; 4) Some political association of the communities concerned prior to their federal union either in a loose confederation, ... or as parts of the same Empire, ...; 5) Geographical neighbourhood; and 6) similarity of political institutions (Wheare, 1963: 37).

Nonetheless, Wheare warned that, "it is not possible to pick on any one of them or any one combination of them and say that unless this or these are present, the desire for federal union will not arise; that desire may be produced by any one of them" (ibid.: 42). For Birch, the last four of Wheare's conditions - a hope of economic advantage from union; some previous political association; geographical neighbourhood; and similarity of political institutions - were present in the creation of the Federation, but the first condition - a sense of military insecurity and the consequent need for common defence - was absent because the French neighbouring countries did not pose any kind of military threat to Nigeria (Birch, 1966: 23). Moreover, Birch argued that the Western Region of Nigeria, which Riker described as "depressed", was in fact the most prosperous of the three Nigerian Regions, and at the time of the bargain Nigerian leaders showed no disposition to sympathise with Nkrumah's ambitions. Armed with empirical evidence, Birch therefore found it easy to dismiss Riker's account of Nigerian federal formation as misleading. However, Afigbo (1991:14) has argued that the geographic and economic configuration of Nigeria cannot be used to make a strong case for any particular government arrangement - unitary, federal or confederal. This counter-argument notwithstanding, it may be misleading to assume that the multicultural nature of the Nigerian society, for instance, can be ruled out in the calculation to federalise the previously unitary state.

According to Watts (1966), the motives for union in the new federations were much more complex than in the old ones, and therefore produced a comprehensive list of socio-economic conditions that predicated the formation of these new federations. Watts' "new Federations" were India, Pakistan, Malaysia, Nigeria, Rhodesia, and the West Indies while the "old Federations" were United States, Switzerland, Canada, and Australia. Watts' conditions are:

1. The desire for political independence; 2 . The hope of economic advantage; 3 . The need for administrative efficiency; 4. The enhancing of the conduct of external relations, both diplomatic and military; 5. a community of outlook based on race, religion, language, or culture; 6. geographical factors; 7. the influence of history; 8 . Similarities and differences in colonial and indigenous political and social institutions; 9. the 
character of political leadership; 10 . The existence of successful older models of federal union; and 11 the influence of the United Kingdom government in constitution-making (Watts, 1966: 42).

This list is similar to that of Wheare, but could be seen as an improvement, and each of the factors is, potentially, either "unifying or separating" (Watts, 1966: 42); "centripetal or centrifugal" (Davis, 1978: 128). Watts concluded his survey of the six new federations by highlighting the two main features common to them all: a geographical distribution of the diversities within each of these societies, which results in the demands for regional political autonomy; and the existence of some form of desire to be united (Watts, 1966.: 93). Watts' main argument is that the impact of political, social, cultural, economic and historical factors cannot be overemphasised in the formation of the modern federations, including Nigeria.

As specifically observed by Watts, the hope of economic advantage, or more precisely, regional economic interdependence, was one of the decisive factors in the federalising process that culminated in the birth of the federation of Nigeria in 1954. Awa had also mentioned that the economies of the territories that later came together were complementary, arguing that the Eastern Region had a large reservoir of unskilled, semi-skilled and skilled labour, the economic success of which was built on palm oil, the Northern Region was rich in groundnut and cotton, while the Western Region was a great producer of cocoa and also had a large reservoir of professionals and bureaucrats (Awa, 1976: 25). These arguments have been corroborated by Suberu (2001: 19; 21; 2004: 330), arguing that the decision to federalise the hitherto unitary state in 1954 owed to "the country's deep cultural fragmentation, the aggravation of this diversity by sundry colonial policies, and the enormous attraction that federalist guarantees of subnational autonomy had for Nigeria's rising political elite".

Similarly, the role played by common historical factors as well as the similarity of political institutions in inducing communities to desire a federal union cannot be overemphasised. Sharing a common historical association has a tendency to exert a unifying influence. This reinforces Watts' argument, that the historical impact of British rule was also a significant factor in the creation of the Nigerian Federation. All regions in the country, despite their differences, shared a history of British rule. Indeed, one of the founding fathers of the country, Dr Nnamdi Azikwe, once described Nigeria as "a political union which has been forged on the anvil of British rule" (Azikwe, 1961: 190 cited in Watts, 1966: 57).

At this juncture, it becomes imperative to turn our attention to one significant factor in the birth of the Nigerian Federation, and that is the desire to form a federal union. According to Wheare, the main driving force behind the formation of a federation is the willingness or desire of communities "to be united, but not to be unitary" (Wheare, 1963: 36, emphasis added). By implication, therefore, what is essential to the formation of a federal union in Wheare's view, is the desire to want to come together under a single political umbrella. Wheare had earlier suggested that as a compromise, the minority nation should be willing to be part of the union, but also that the majority nation should be prepared to tolerate the existence of the minority nation (Wheare, 1962). Concurring with Wheare, Watts also argued that the main distinguishing characteristic of the old federations was the existence of a desire to be united under a single general government, and specifically that one of the main motives for the formation of the 
Nigerian Federation is the desire for political independence from the British colonial authorities (Watts, 1966: 43, emphasis added). Watts' notion of "desire" in the creation of a federal union came under attack from Davis, arguing that it is not possible to measure a "balance of desire", and therefore, "a theory of federal parturition relying on a balance of ambivalent desires" cannot explain why federal unions are formed (Davis, 1978: 141). But Burgess (2006: 81), who has also criticised Riker for abuse of history, amplified Wheare's and Watts' positions, arguing that analytically, there is a two-step process involved in the creation of a federation: the first is the desire for a union, while the second is the decision to have a federal union. Burgess, whose claim is predicated on his study of the federations of Switzerland, Canada, Australia, India, Malaysia, Austria and Germany, found Riker's "framework of analysis" wanting (ibid.: 100).

It is instructive to point out at this stage that during the decolonisation period, Nigerian political leaders favoured a federal state on the ground that federalism would guarantee the accommodation of diversity in the country. This brings us to another important factor that cannot be ignored in the origin of the federation, and that is the role of leadership, a factor that was later alluded to by Wheare and echoed by other scholars after him, arguing that able leadership is needed to translate the desire for federation into reality. For instance, Watts (1966: 61) had argued that federations are based on compromises, which require political leadership capable of being conciliatory, and that the influence and charismatic leadership of Nehru and Gandhi played a significant part in the formation of the Indian Federation. Also, the importance of the leadership factor in the formation of a federal union was emphasised by Awa, arguing that, "all the other factors which help in the formation of a federation" are "merely the raw materials which underlie the formation of a union" (Awa, 1976: 30-1; see also Eleazu, 1977: 18). In Nigeria, regional leaders, using their ethno-regional political parties as platforms, promoted the idea of federalism.

Nigerian regional leaders were very active in their collaboration with the British authorities in advocating the federal idea. Southern elites, notably Nnamdi Azikiwe and Obafemi Awolowo, favoured a federal system of government, believing that federalism would promote unity in diversity. For example, Azikiwe had in his book, Political Blueprint of Nigeria, published in 1943, envisaged a federal commonwealth of Nigeria, made up of eight "protectorates" based on ethnic affiliation, while Awolowo also used his book, Path to Nigerian Freedom, published in 1947, to argue that only a federal system would suit Nigeria's political conditions. It is important to point out here that Nigerian leaders actively participated in the various Constitutional Conferences that culminated in the Federal Constitution of 1954. There was a political bargain between Nigerian regional political leaders, and not between national and constituent leaders as contended by Riker. This bargain took place during the Ibadan Constitutional Conference of 1951 and the London Constitutional Conference of 1954, where these regional leaders jettisoned their differences to arrive at a compromise. Nigerian leaders arrived at a federal idea, believing that "only federal states have the institutional and structural capacity both to accommodate and reconcile different forms of unity with different forms of diversity" (Burgess, 1999: 1).

Another indication that federalism was negotiated, agreed and welcomed by all regional leaders emerged when Dr Nnamdi Azikwe, who became a member of the federal House of Representatives in 1954, remarked that, "as for me and those who think like me politically, we are determined to make the revised constitution an avenue for holding the 
country together through a strong federal government" (NAI, NL/H2 Nigeria, House of Representatives Debates, Third Session, March 8, 1954: 37 quoted in Osadolor, 1998: 43, emphasis added). In a similar vein, the country's first prime minister, Sir Abubakar Tafawa Balewa, remarked in the federal House of Representatives in 1957 that, "I am pleased to see that we are all agreed that the federal system is, under the present conditions, the only sure basis on which Nigeria can remain united" (Tafawa Balewa, Mr Prime Minister, p.2 quoted in Adamolekun and Ayo, 1989: 157). According to Awa (1964: 48), these leaders "regarded federalism as a philosophy of opportunity" in which every federating unit would be allowed to develop at the pace determined by the ability of its leaders and by its natural resources (see also Suberu, 2001: 25; Elaigwu, 2007: 25; Oyovbaire, 1983: 9; 13). This again reinforces our assertion that the decision to federalise the previously unitary state was characterised by concessions and compromises. It also attests to the view that, generally, federation is a child of compromise, an equilibrium between centrifugal and centripetal forces, or "a perfect balance or compromise between the extremes" (Maddox, 1941: 1121). Therefore, it is our contention in this paper that it is misleading to argue that a federal political framework was imposed on Nigeria; such argument is a misinterpretation of Nigeria's political history.

It may be argued that the British colonial authorities 'sold' the idea of federalism to Nigeria's regional leaders because the British wanted their creation to survive even after their departure. For the British, therefore, the differences among the Nigerian peoples in terms of language, religion and historical background could only be accommodated in a federal political system, where each region would be allowed to maintain its identity and yet remain in a federal Nigeria. For Osuntokun (1979: 98-9), the promotion of the federal idea by the British colonial authorities "was not out of altruistic motives. British investment in Nigeria was already substantial and it was not in the interest of British capitalists to see the edifice ... collapse like a house of cards", given the fact that Nigeria was then the largest market in Africa for raw materials for British industries.

\section{The Rikerian Theory: A Scientific Fallacy}

There is no doubt that scholars familiar with the history of federalism in Nigeria hold divergent views on the factors responsible for the federalising process: some have leaned towards the position that the presence of social and economic factors are responsible, while others have contended that the impact of British colonialism was the decisive factor in the decision to federalise the hitherto unitary state, but none seems to be sympathetic to the Rikerian thesis. In this paper, it has been demonstrated thus far that the factors that gave birth to the Nigerian Federation are many, and much complex than Riker would want us to believe. For example, federalism was promoted in Nigeria by the British colonial authority, first for administrative convenience, and later as a basis for constitutional reform and for economic reasons. Economic interdependence, the desire to achieve independence and the effect of common British rule, all contributed to lay the foundation for a federal system for the country. It thus appears merely convenient to argue that imperatives of administrative convenience and the existence of certain social, political, economic, historical and geographical conditions combined to give birth to the Nigerian Federation. Most significantly, the federal solution was necessitated by the desire to achieve 'unity in diversity'. Therefore, Riker's rejection of social and economic conditions in the creation of federations, and his exclusive focus on 
political conditions, render his theory inadequate to explain the formation of a federation like Nigeria. In other words, it is misleading to suggest that the origin of the Nigerian Federation followed the same process as that of the United States.

The question at this juncture, therefore, is: How valid is Riker's 'theory' of federal formation, especially in relation to Nigeria? Validity is needed in order to arrive at generalisation (Bell, 1999). It is important that empirical measures are valid because they result in the formulation of a theory, but if not, it is more likely that decisions made based on the results of that measure will be erroneous, as aptly demonstrated with the Rikerian theory. For instance, Riker's external threat condition remains a trivial one, and this makes generalisation difficult. Generalisability refers to the extent that the results of the research and analysis apply to a wider group than just the ones investigated in the original study (King, Keohane \& Verba, 1994). Like reliability and validity, generalisability is also considered as a criterion for assessing the quality of social science research.

One may therefore conclude that Riker's reliance on the political conditions that gave birth to the American Federation to make a generalisation, as well as the rejection of social and economic factors in the origin of federations lack scientific attributes. One finds it difficult not to concur with the empirical postulations provided by eminent scholars sympathetic to the socio-economic theory of federal formations. In other words, the socio-economic theory may best be used to explain the origin of the Nigerian Federation. Nevertheless, the Rikerian theory, as controversial as it has been, also provides any student of federalism with a route to the study of federal political systems. 


\section{References}

1. Adamolekun, L and Ayo, B. (1989) 'The Evolution of the Nigerian Administration System', Publius: The Journal of Federalism, 19, 157-176.

2. Afigbo, A. (1991) 'Background to Nigerian Federalism: Federal Features in the Colonial State', Publius: The Journal of Federalism, Vo1. 21, No. 4, 13-20.

3. Awa, E. (1964) Federal Government in Nigeria, Berkeley and Los Angeles: University of California Press.

4. Awa, E. (1976) Issues in Federalism, Benin City: Ethiope Publishing Corporation.

5. Awolowo, O. (1974) Path to Nigerian Freedom, London: Faber and Faber Ltd.

6. Bell, J. (1999) Doing Your Research Project: A Guide for First-Time Researchers in Education and Social Science 3rd Edition, Buckingham: Open University Press.

7. Birch, A. H. (1966) 'Approaches to the Study of Federalism', Political Studies, 14, 15-33.

8. Burgess, M. (1999) 'Obstinate or Obsolete? The State of the Canadian Federation', Regional \& Federal Studies, Vol. 9, No. 2, 1-15.

9. Burgess, M. (2006) Comparative Federalism: Theory and Practice, London, New York: Routledge.

10. Davis, S. R. (1978) The Federal Principle: A Journey Through Time in Quest of Meaning, Berkeley, Los Angeles, London: University of California Press.

11. Deutsch, K., et al. (1957) Political Community in the North Atlantic Area, Princeton, NJ, Princeton University Press.

12. Dikshit, R. D. (1971) 'Military Interpretation of Federal Constitutions: A Critique', The Journal of Politics, 33, 180-189.

13. Dikshit, R. D. (1975) The Political Geography of Federalism: An Enquiry into Origins and Stability, New Delhi, Macmillan.

14. Elaigwu, J.I. (2006) 'The Federal Republic of Nigeria', in Majeed A, Watts R.L., and Brown D.M (eds.), A Global Dialogue on Federalism, Vol. II, Montreal \& Kingston: McGill-Queens' University Press.

15. Elaigwu, J.I. (2007) The Politics of Federalism in Nigeria, London: Adonis \& Abbey Publisher Ltd.

16. Eleazu, U.O. (1977) Federalism and Nation Building: The Nigerian Experience 1954-1964, Devon: Arthur H. Stockwell Ltd. 
17. Hicks, U.K. (1978) Federalism: Failure and Success. A Comparative Study, London and Basingstoke: The Macmillan Press Ltd.

18. King, P. (1982) Federalism and Federation, Baltimore: Johns Hopkins University Press.

19. King, G., Keohane, R. \& Verba, S. (1994) Designing Social Inquiry: Scientific Inference in Qualitative Research, Chichester: Princeton University Press.

20. Maddox, W. (1941) 'The Political Basis of Federation', The American Political Science Review, Vol. 35, No. 6, 1120-1127.

21. McKay, D. (2004) 'William Riker on Federalism: Sometimes Wrong but More Right than Anyone else?' Regional \& Federal Studies, 14: 2, 167-186.

22. Osadolor, O.B. (1998) 'The Development of the Federal Idea and the Federal Framework, 1914-1960', in Amuwo et. al., (eds.), Federalism and Political Restructuring in Nigeria, Ibadan, Nigeria: Spectrum Books Limited and IFRA.

23. Osuntokun, J. (1979) 'The Historical Background of Nigerian Federalism', in Akinyemi et al. (eds.), Readings on Federalism, Lagos: The Nigerian Institute of International Affairs (NIIA).

24. Oyovbaire, S.E. (1983) 'Structural Change and Political Processes in Nigeria' African Affairs, 82, 326, 3-28.

25. Riker, W. (1964) Federalism: Origin, Operation, Significance, Boston: Little, Brown and Company.

26. Stepan, A. (2001) Arguing Comparative Politics, Oxford: Oxford University Press.

27. Stepan, A. (2005) 'Federalism and Democracy: Beyond the US Model', in Karmis, D. and Norman, W. (eds.), Theories of Federalism: A Reader, New York and Basingstoke: Palgrave Macmillan.

28. Suberu, R. (2001) Federalism and Ethnic Conflict in Nigeria, Washington, D.C.: United States Institute of Peace Press.

29. Suberu, R. (2004) 'Nigeria: Dilemmas of Federalism', in Amoretti, U.M and Bermeo, N (eds.), Federalism and Territorial Cleavages, Baltimore and London: The Johns Hopkins University Press.

30. Watts, R. (1966) New Federations: Experiments in the Commonwealth, Oxford: The Clarendon Press.

31. Wheare, K. C. (1962) 'Federalism and the Making of Nations' in Macmahon, A.W (ed.), Federalism: Mature and Emergent, New York: Russell \& Russell Inc.

32. Wheare, K. C. (1963) Federal Government, 4th ed., London: Oxford University Press. 